\title{
Radioactive-Waste Classification in the United States: History and Current Predicaments
}

\author{
M. D. Lowenthal
}

July 1997

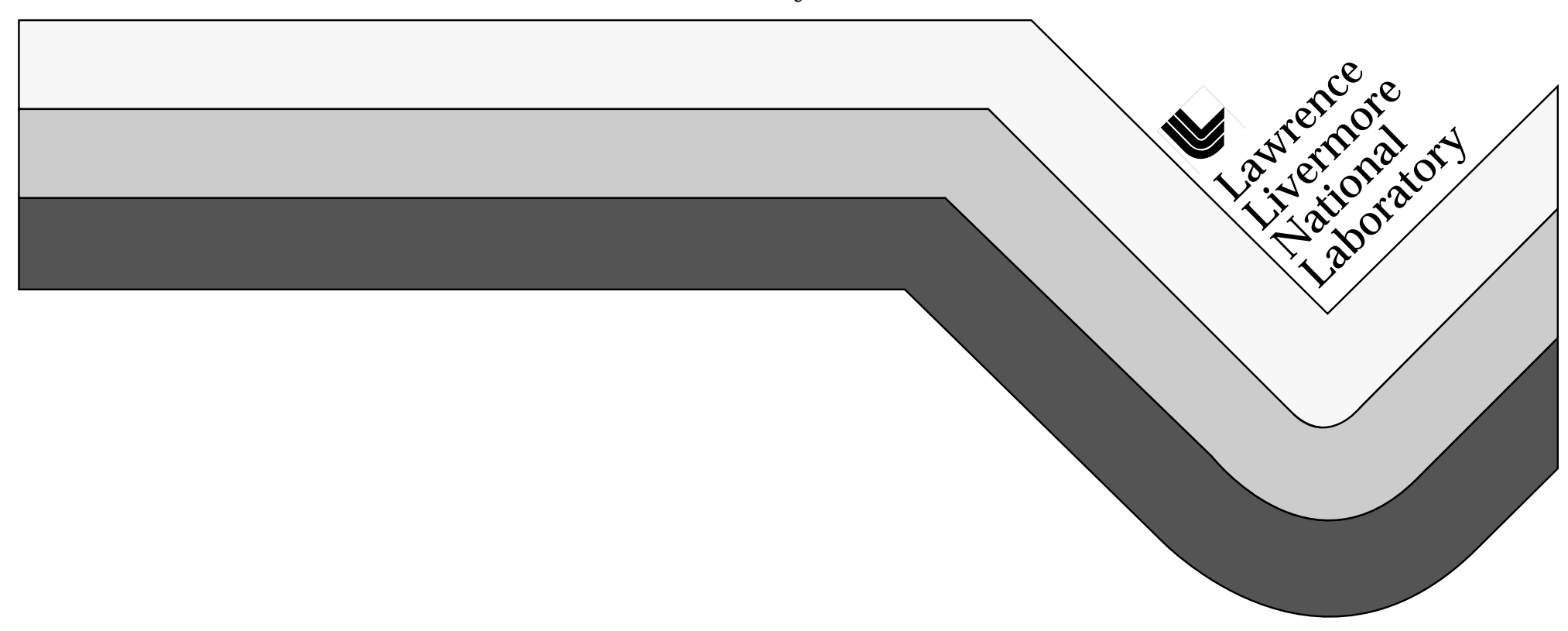




\section{DISCLAIMER}

This document was prepared as an account of work sponsored by an agency of the United States Government. Neither the United States Government nor the University of California nor any of their employees makes any warranty, express or implied, or assumes any legal liability or responsibility for the accuracy, completeness, or usefulness of any information, apparatus, product, or process disclosed, or represents that its use would not infringe privately owned rights. Reference herein to any specific commercial products, process, or service by trade name, trademark, manufacturer, or otherwise does not necessarily constitute or imply its endorsement, recommendation, or favoring by the United States Government or the University of California. The views and opinions of authors expressed herein do not necessarily state or reflect those of the United States Government thereof, and shall not be used for advertising or product endorsement purposes.

The opinions expressed herein are those of the author.

Work performed under the auspices of the U.S. Department of Energy by Lawrence Livermore National Laboratory under Contract W-7405-Eng-48. 


\title{
Radioactive-Waste Classification in the United States: History and Current Predicaments
}

\author{
Micah D. Lowenthal \\ Center for Nuclear and Toxic Waste Management \\ University of California \\ Berkeley, California 94720-1730
}





\section{Contents}

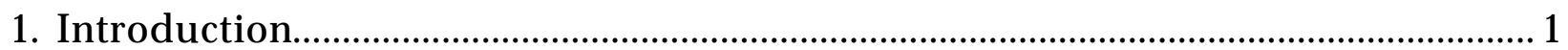

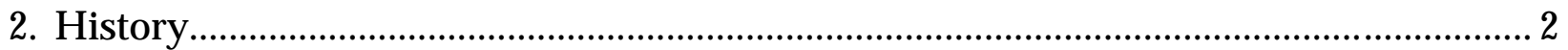

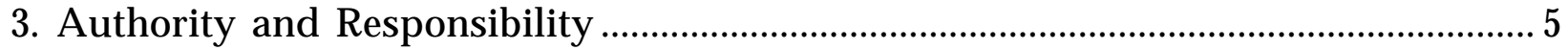

4. Definitions of Waste: What is Waste, What is Not Waste, What are the Classes ............................................................... 7

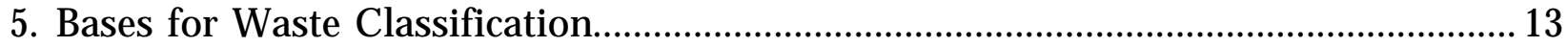

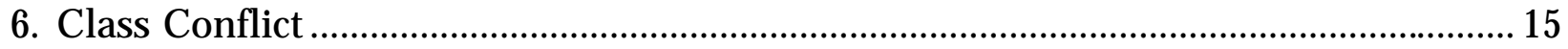

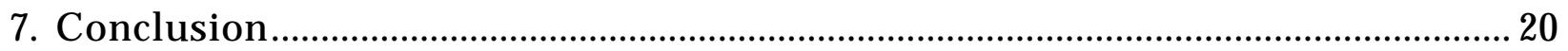

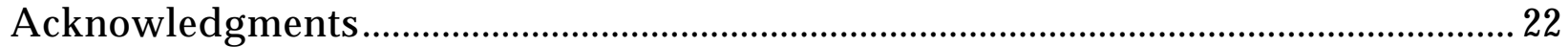

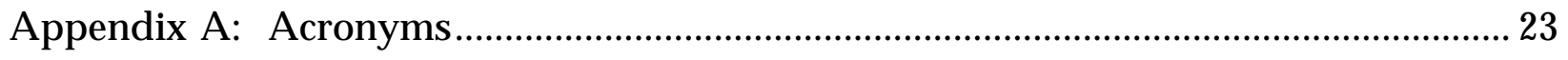

Appendix B: A Comparison of LLW Concentration Limits ......................................25

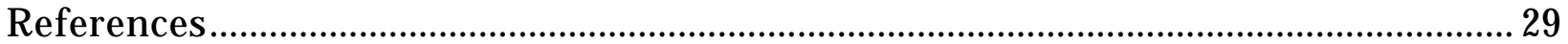




\section{Radioactive-Waste Classification in the United States: History and Current Predicaments}

\section{Introduction}

From the outset of the nuclear age, focus on things nuclear has centered more on the activities that generate nuclear waste than on the characteristics of the wastes generated or on the management of those wastes. Waste classes were based primarily on practical factors of immediate concern, such as exposure rates and proliferation security, or on the process that produced the waste. But waste classification is undergoing a slow shift in bases from source-defined classes to more particularistic classes prescribed by characteristics of the disposal site and facility. This shift reflects the broadening of attention in the last 25 years to include recognition of disposal as a significant and potentially consequential activity. As citizens, scientists, engineers, law makers, and regulators have gained a better understanding of the consequences of disposal, regulations have changed to recognize first the importance of other waste characteristics in addition to exposure rates, and later the importance of interactions between the disposal environment and the waste. The growth of waste-management activities in both scope and scale over the last two decades has underscored the need for a consistent scheme for waste classification and has highlighted some of the deficiencies of the current U.S. system whereby some classes are strategically defined while others result from circumstance, legacy, or omission. This paper provides a description of wasteclassification schemes used in the United States at the federal level, some of the history associated with these schemes, both in the civilian and the government sectors, and explores the consequences of inconsistencies, overlaps, and omissions. These unwanted consequences result from a conflict between our generatororiented, top-down waste classes and our disposer-oriented, bottom-up wasteacceptance criteria. I argue that we should take a more integrated approach to management of wastes and that we have a window of opportunity to carry this out in the next few years. Alternative approaches to classification are addressed in a companion paper, to follow.

Our current dilemmas are partly rooted in how the waste classes developed; thus we begin with a history of waste classification in the United States. 


\section{History}

The United States was the first nation on earth to produce a self-sustaining nuclear reactor (Fermi's Chicago pile, 1942) and was also the first nation to detonate a nuclear weapon (Trinity test, 1945). Policies regarding nuclear materials have developed within a context that includes both government-promoted nuclear power and an enormous government-run nuclear weapons complex. The early secrecy surrounding nuclear materials and technology prompted legislation creating an Atomic Energy Commission (the AEC, created by the McMahon Atomic Energy Act of 1946 [1]) to develop and protect this new technology. The Atomic Energy Amendments Act of 1954 [2] (hereafter the AEA) superseded previous legislation, providing for broader control of nuclear materials and making possible the creation of a civilian nuclear power program. The AEA, as amended, is the law that defines and restricts access to nuclear materials and is the law by which Congress endows agencies with the authority to manage and regulate nuclear materials. ${ }^{1}$ These agencies create policies and regulations that must be consistent with Congress' statutes.

Early in the pursuit of nuclear power, radioactive-waste disposal was recognized as an issue to be resolved, but of no pressing urgency. At the request of the AEC, the National Academy of Sciences-National Research Council (NAS-NRC) considered the feasibility of land disposal of radioactive wastes. In 1957 the NASNRC reported that land disposal does appear to be feasible in a number of locations within the United States (salt beds and salt domes were "suggested as the possibility promising the most practical immediate solution of the problem." [4]), although these "considered opinions" were expressed with the understanding that research was needed before any final conclusions could be reached. An early effort at disposal in salt-a salt mine in Lyons, Kansas-fell apart in 1971 when the site proved to be poorly chosen (the site was extensively drilled).

The failed effort in Lyons contributed to the perception that the AEC and its descendents were far from solving the disposal problem for radioactive waste. Accidents and failures at shallow-burial trenches, including fires and leaching of mobile $\alpha$-emitters at almost every one of the AEC disposal sites, resulted from insufficient restrictions on waste streams, such as permitting shallow burial of transuranics and unstabilized hazardous chemicals [5]. Partly as a result of these problems, the government incrementally introduced radioactive waste classes. The

\footnotetext{
1 "Radioactive materials covered by the Atomic Energy Act are those encompassed in its definition of source, byproduct, or special nuclear materials. Examples of materials not covered include radium and accelerator-produced isotopes. See Train v. Colorado Public Interest Research Group, Inc., 426 U.S. 1 (1976)." [3]
} 
first, and until the 1970s the only, official distinction between different kinds of radioactive waste was between high-level waste (aqueous waste from the first cycle solvent-extraction in reprocessing spent nuclear fuel) and "other than high level" waste [5]. In 1971 the AEC restricted disposal practices for transuranic wastes. Other waste classes were introduced by specific legislation that usually addressed only part of the the radioactive waste picture. This incremental approach to waste classification yielded the eclectic system described later, in Section 4.

In the late 1960s and early 1970s national environmental legislation was passed $^{2}$ and the Environmental Protection Agency (EPA) was created by Reorganiazation Plan Number 3 in 1970. Having passed legislation concerning visible environmental problems such as brown air and burning rivers, invisible threats to human health emerged on Congress' and the nation's agenda. Driven partly by toxic-waste horror stories such as Love Canal and Times Beach, government turned uprecedented attention to waste disposal and cleanup with major amendments to the Solid Waste Disposal Act of 1965 [6], namely the Resource Conservation and Recovery Act of 1976 (RCRA) [7] and the Comprehensive Environmental Response, Compensation, and Liability Act of 1980 (CERCLA) [8]. This attention reached the nuclear sector in the late 1970s beginning with legislation to address the difficult issue of uranium-mill tailings: the Uranium Mill Tailings Radiation Control Act of 1978 [9]. This was followed by the Low-level Radioactive Waste Policy Act in 1980 [10], the Nuclear Waste Policy Act in 1982 [11], and their respective amendments ([12],[13]).

The regulatory sector underwent major changes in the 1970s: the Atomic Energy Commission was broken into the Nuclear Regulatory Commission (NRC) and the Energy Resource and Development Administration (ERDA, later to become the Department of Energy, DOE) by the Energy Reorganization Act of 1974 [14], when Congress found it in the public interest to separate the licensing and regulation of nuclear power from the development and promotion of nuclear power. Through this period, until the Federal Facility Compliance Act of 1992 [15], the AEC followed by the DOE was responsible for standards-setting, management, execution, and regulation for its own activities. DOE's radioactive waste policies [16] were revised to reflect legislation and policies were developed to carry out many of the statutory dictates. While the AEC and its descendants, the NRC and DOE, retained authority over radiation safety, the EPA was given authority to set standards for routine

\footnotetext{
${ }^{2}$ The Water Quality Act of 1965, the Solid Waste Disposal Act of 1965, the Air Quality Act of 1967, the National Environmental Policy Act of 1969, the Clean Air Act Amendments of 1970 and the Federal Water Pollution Control Act of 1972.
} 
emissions of radioactive materials into the air and water, and later for cleanup of contaminated sites and exposures from waste disposal sites.

President Carter officially deferred reprocessing of spent nuclear fuel due to nuclear proliferation concerns in 1977. Until that time it was presumed that civilian spent fuel, like military spent fuel, would be reprocessed to recover the remaining plutonium and fissile uranium. President Reagan reversed Carter's order but, due to a combination of economics and politics, both unfavorable, commercial reprocessing never resumed in the United States and aside from a small amount ( 650 MTU [5]) of spent fuel reprocessed in West Valley, New York, before a plant there shut down, all commercial spent fuel in the United States has sat in cooling pools or in dry concrete storage casks, mostly at reactor sites awaiting disposal. ${ }^{3}$ The AEC, followed by the DOE, continued production of plutonium and tritium for weapons until 1991 when it was deemed that the surplus stockpile was more than sufficient to supply the weapons needs of the nation. DOE and the Naval Nuclear Propulsion Program jointly reprocessed the highly enriched spent fuel from naval reactors at the Idaho National Engineering Laboratory (INEL, now known as the Idaho National Engineering and Environmental Laboratory, INEEL) until 1992 when DOE decided that the costs of reprocessing outweighed the benefits, due partly to its diminishing demand for highly enriched uranium. The wastes from the Naval Nuclear Propulsion Program are not subject to DOE policies (section 8(f) of Ref. [16]), but are subject to the same statutes and standards mentioned above. DOE now conducts or plans decommissioning, cleanup, and disposal efforts for a wide range of projects, materials, and facilities.

\footnotetext{
${ }^{3}$ Some commercial spent fuel is stored at the Idaho National Engineering and Environmental Laboratory and at the Midwest Fuel Recovery Plant, a reprocessing facility that never operated due to design flaws. Some fuel from the Shippingport reactor is stored at Hanford [17].
} 


\section{Authority and Responsibility}

As mentioned above, the Atomic Energy Act of 1954, as amended [18], is the basic law governing production of, use of, ownership of, liability for, and disposal of radioactive materials in the United States. A number of laws also specify radioactive-waste-management procedures and authorities. In 1980 Congress passed the Low-Level Radioactive Waste Policy Act (LLWPA, amended in 1985, LLWPAA) making disposal of non-DOE LLW a responsibility of the states, and making disposal of commercial transuranic waste and "greater than Class C" low-level waste (see Table 1) a federal responsibility. According to these laws, EPA must set radiation protection standards for disposal of LLW, supplementing standards set by NRC, but EPA has not as yet established this regulation.

Congress passed the Nuclear Waste Policy Act (NWPA) in 1982, which prescribes the form of disposal for high-level waste and spent fuel and sets deadlines for progress. Although the topic is socially divisive and controversial, legislators struck compromises that made the act politically palatable. The NWPA contains mechanisms that force creation of two repositories, one in the east and one in the west, so that neither region bears the entire burden. The Act also lists potential sites in those regions. To alleviate concerns that a temporary storage site might become a permanent resting ground, the Act prohibits construction of a centralized temporary storage prior to construction of a repository. The NWPA Amendments of 1987 (NWPAA) named Yucca Mountain, Nevada, as the only site of the original set to be extensively characterized, with the hope that it will become the first U.S. HLW repository. The EPA is charged with the task of setting standards for the repository and the NRC will decide whether to issue DOE a licence for the repository based on these standards. The law requires site-specific assessment to establish compliance with the standards. In the Energy Policy Act of 1992, Congress, dissatisfied with EPA's standards, required EPA to promulgate new standards to ensure protection of the health of individual members of the public and asked the NAS-NRC to advise EPA on the technical bases for these standards. The NAS-NRC made its recommendations in 1995 [19] but EPA has not yet promulgated its standards.

Responsibilities for management of nuclear materials in the United States, including radioactive wastes, are defined in the above-mentioned laws passed by Congress and these laws are administered by government agencies that codify the details in the Code of Federal Regulations, in guidance documents, and in internal orders. Responsibilities for action, monitoring, enforcement, and standard-setting are divided between several agencies: DOE, EPA, NRC, and the Department of Transportation (DOT) are all involved in different aspects of radioactive waste 
management for DOE projects on the federal level. Management of wastes from other generators involve the same agencies and even include DOE for high-level waste and greater-than-class-C low-level waste. Some individual states have created state agencies similar to the federal or U.S. NRC and U.S. EPA. By separate agreements, the U.S. NRC and U.S. EPA can delegate authority to regulate nuclear materials to those state agencies. Despite the fact that all of these federal agencies are parts of the same government, disputes between them have occasionally led to major conflicts [20]. 


\section{Definitions of Waste: What is Waste, What is Not Waste, What are the Classes}

Most nations categorize wastes into classes in order to simplify wastemanagement actions, rules, and regulations while protecting human health. The extent to which the waste-classification systems are successful at achieving these goals is the subject of some debate and little agreement. A reasonable place to begin with waste classification might be to try to define the term "radioactive waste." The DOE has a definition of radioactive waste: "Solid, liquid, or gaseous material that contains radionuclides regulated under the Atomic Energy Act of 1954, as amended, and of negligible economic value considering costs of recovery" (Attachment 2 of Ref. [16]). The last part of this definition has led some analysts to refer to an "economic recovery limit" which determines when otherwise valuable material becomes waste-a conceptually acceptable, if practically troubled, definition of waste.

While a substance that has no value can indeed be called waste, the economic basis subjects the definition to the transitory and subjective nature of valuation. What is waste under one set of assumptions at one time may be of value under another set of assumptions or at a later time. The most prominent example of shifting valuation is the approximately 50 metric tons of weapons-grade plutonium $(\mathrm{wPu})$ recently declared as "excess." The end of the Cold War and the attendant build-down of the nuclear-weapons stockpile has changed the value of the wPu. For five years or more the United States has been studying, discussing, planning, and debating ways to manage or dispose of $\mathrm{wPu}$. The possibility that this material might be considered waste was inconceivable to law makers and regulators alike no more than 10 years ago-thus there is no appropriate waste class for the material. ${ }^{4}$ Indeed, there is still no consensus regarding the value of the material and converting it to a disposable waste form is one of two options that DOE is developing. We get little further clarification and few alternatives for definitions of waste from other laws and regulations. While the AEA does specify a number of waste and material classes, listed in Tables 1-3, it does not clearly distinguish what is regulated from what is not. The economic recovery limit remains as our only definition.

\footnotetext{
${ }^{4}$ Technically, wPu could be transuranic waste, but due to criticality concerns it would never meet the waste acceptance criteria for any disposal site without substantial dilution (to a volume of at least $50,000 \mathrm{~m}^{3}$, using WIPP's waste acceptance limit of 200 grams ${ }^{239} \mathrm{Pu} / 55$ gallon drum). It fits the "special nuclear material" class, but this is not a waste class, except in that disposal sites must be specially licensed to accept special nuclear material.
} 
Table 1. Definitions of radioactive waste classes according to statutes and regulations.

\begin{tabular}{|c|c|}
\hline Waste Class & Definition \\
\hline $\begin{array}{l}\text { High-Level Waste } \\
(\text { HLW) }\end{array}$ & $\begin{array}{l}\text { (A) the highly radioactive material resulting from the reprocessing of spent } \\
\text { nuclear fuel, including liquid waste produced directly in reprocessing and any } \\
\text { solid material derived from such liquid waste that contains fission products in } \\
\text { sufficient concentrations; and (B) other highly radioactive material that the } \\
\text { Commission, consistent with existing law, determines by rule requires } \\
\text { permanent isolation. [21] } \\
\text { The Commission has determined that irradiated reactor fuel shall, for the } \\
\text { purposes of the repository, be considered HLW. [22] }\end{array}$ \\
\hline $\begin{array}{l}\text { Spent Nuclear Fuel } \\
\text { (SNF) }\end{array}$ & $\begin{array}{l}\text { Fuel that has been withdrawn from a nuclear reactor following irradiation, } \\
\text { the constituent elements of which have not been separated by reprocessing. } \\
\text { [22]. Under } 10 \text { CFR } 60 \text {, spent nuclear fuel is regulated as HLW. }\end{array}$ \\
\hline $\begin{array}{l}\text { Transuranic Waste } \\
\text { (TRUW) }\end{array}$ & $\begin{array}{l}\text { This class is specfic to waste streams from DOE and comprises "material } \\
\text { contaminated with elements that have an atomic number greater than 92, } \\
\text { including neptunium, plutonium, americium, and curium, and that are in } \\
\text { concentrations greater than } 10 \text { nanocuries per gram, or in such other } \\
\text { concentrations as the Nuclear Regulatory Commission may prescribe to protect } \\
\text { the public health and safety." [23] This definition was revised in } 1984 \text { by } \\
\text { DOE Order } 5820.2 \text { to be "Without regard to source or form, waste that is } \\
\text { contaminated with alpha-emitting transuranium radionuclides with half- } \\
\text { lives greater than } 20 \text { years and concentrations greater than } 100 \mathrm{nCi} / \mathrm{g} \text { at the } \\
\text { time of assay." (Attachment } 2 \text { of Ref. [16]) }\end{array}$ \\
\hline $\begin{array}{l}\text { Uranium Mining and } \\
\text { Mill Tailings }\end{array}$ & $\begin{array}{l}\text { The tailings or wastes produced by the extraction or concentration of uranium } \\
\text { or thorium from any ore processed primarily for its source material content. } \\
\text { Also called byproduct materials under } 42 \text { U.S.C. } \S 2014 \text { (e)(2). }{ }^{\text {a }}\end{array}$ \\
\hline $\begin{array}{l}\text { Low-Level Waste } \\
\text { (LLW) }\end{array}$ & $\begin{array}{l}\text { "Radioactive material that (A) is not high-level radioactive waste, spent } \\
\text { nuclear fuel, or byproduct material (as defined in [23]); and (B) the Nuclear } \\
\text { Regulatory Commission, consistent with existing law and in accordance with } \\
\text { paragraph (A), classifies as low-level radioactive waste." [24] } \\
\text { This does not exclude commercial TRU waste. In the government sector, TRU } \\
\text { waste is excluded. } \\
\text { LLW is divided into two broad categories: waste that qualifies for near- } \\
\text { surface burial, and waste that requires deeper disposal. The criteria for near- } \\
\text { surface burial are that the external exposure to a member of the public } \\
\text { resulting from release of the waste shall not exceed } 25 \text { mrem/year, effective } \\
\text { dose equivalent; atmospheric releases shall not exceed limits in the National } \\
\text { Emission Standards for Hazardous Air Pollutants (NESHAPS, [25]); the dose } \\
\text { (DOE Order uses "effective dose equivalent," } 10 \text { CFR } 61 \text { uses "whole-body } \\
\text { dose") to a person who inadvertently intrudes into the disposal site (under } \\
\text { specified scenarios) after loss of institutional control (100y), shall not exceed a } \\
\text { one-time commitment of } 5 \text { mSv or an annual dose of } 1 \text { mSv for first 1000y after } \\
\text { emplacement. } \\
\text { LLW that is regulated by the NRC and qualifies for near surface burial is } \\
\text { separated into the three classes described in Table } 2 \text {. DOE LLW is } \\
\text { subclassified according to facility-specific limitations. }\end{array}$ \\
\hline
\end{tabular}


Table 1. (continued).

\begin{tabular}{|l|l|}
\hline \multicolumn{1}{|c|}{ Waste Class } & \multicolumn{1}{c|}{ Definition } \\
\hline $\begin{array}{l}\text { Naturally Occurring } \\
\text { and Accelerator- } \\
\text { produced Radioactive }\end{array}$ & $\begin{array}{l}\text { "Naturally occurring radioactive material and accelerator-produced } \\
\text { radioactive material lie outside NRC's regulatory authority and are subject to } \\
\text { Materials }\end{array}$ \\
$\begin{array}{l}\text { hoRM/Nh and safety regulation by the States and other Federal agencies" [26]. } \\
\text { The waste is generally subclassified as diffuse }\left(<2 \mathrm{nCi} / \mathrm{g}{ }^{226} \mathrm{Ra} \text { or equivalent }\right) \\
\text { or discrete }\left(>2 \mathrm{nCi} / \mathrm{g}{ }^{226} \mathrm{Ra} \text { or equivalent) [17]. They are under review by EPA }\right. \\
\text { and may be regulated under TSCA or RCRA [27]. }\end{array}$ \\
\hline
\end{tabular}

a "In the licensing and regulation of byproduct material, as defined in section 2014(e)(2) of this title, or of any activity which results in the production of byproduct material ... a State shall require (1) compliance with the requirements of subsection (b) of section 2113 of this title (respecting ownership of byproduct material and land), and (2) compliance with standards which shall be adopted by the State for the protection of the public health, safety, and the environment from hazards associated with such material which are equivalent ... or more stringent than, standards adopted and enforced by the Commission for the same purpose..."[24].

Table 2. Subclasses of low-level waste according to the NRC (10 CFR 61 [28]).

\begin{tabular}{|l|l|}
\hline \multicolumn{1}{|c|}{ LLW Waste Class } & \multicolumn{1}{c|}{ Definition } \\
\hline Class A & $\begin{array}{l}\text { Low levels of radiation and heat, no shielding required to protect workers or } \\
\text { public, rule of thumb states that it should decay to acceptable levels within } \\
100 y .\end{array}$ \\
\hline Class B & $\begin{array}{l}\text { Has higher concentrations of radioactivity than Class A and requires greater } \\
\text { isolation and packaging (and shielding for operations) than Class A waste. }\end{array}$ \\
\hline Class C & $\begin{array}{l}\text { Requires isolation from the biosphere for 500 years. Must be buried at least 5m } \\
\text { below the surface and must have an engineered barrier (container and } \\
\text { grouting). }\end{array}$ \\
\hline Greater Than Class C & $\begin{array}{l}\text { This is the LLW that does not qualify for near-surface burial. This includes } \\
\text { commercial transuranics (TRUs) that have half-lives }>5 y \text { and } \\
\text { activity }>100 n C i / g . ~\end{array}$ \\
\hline
\end{tabular}


Table 3. Definitions of material designations that qualify waste classifications.

\begin{tabular}{|c|c|}
\hline Material Designation & Definition \\
\hline $\begin{array}{l}\text { Special Nuclear } \\
\text { Material (SNM) }\end{array}$ & $\begin{array}{l}\text { "(1) plutonium, uranium enriched in the isotope } 233 \text { or in the isotope } 235 \text {, and } \\
\text { any other material which the Commission, pursuant to the provisions of } \\
\text { section } 2071 \text { of [title } 42 \text { of the USC], determines to be special nuclear material, } \\
\text { but does not include source material; or (2) any material artificially enriched } \\
\text { by any of the foregoing, but does not include source material." [23] }\end{array}$ \\
\hline Source Material & $\begin{array}{l}\text { Material that is essential to the production of special nuclear material. [29] } \\
\text { "(1) uranium, thorium, or any other material which is determined by the } \\
\text { Commission pursuant to the provisions of section } 2091 \text { of [title } 42 \text { of the U.S.C.] } \\
\text { to be source material; or (2) ores containing one or more of the foregoing } \\
\text { materials, in such concentration as the Commission may by regulation } \\
\text { determine from time to time." [23] }\end{array}$ \\
\hline $\begin{array}{l}\text { By-Product Material } \\
\text { (11(e) material) }\end{array}$ & $\begin{array}{l}\text { "(1) any radioactive material (except special nuclear material) yielded in or } \\
\text { made radioactive by exposure to the radiation incident to the process of } \\
\text { producing or utilizing special nuclear material, and (2) the tailings or wastes } \\
\text { produced by the extraction or concentration of uranium or thorium from any ore } \\
\text { processed primarily for its source material content." [23] }\end{array}$ \\
\hline $\begin{array}{l}\text { Transuranic Material } \\
\text { (TRU) }\end{array}$ & $\begin{array}{l}\text { Material containing or contaminated with elements that have an atomic } \\
\text { number greater than } 92 .\end{array}$ \\
\hline $\begin{array}{l}\text { Contact Handled } \\
(\mathrm{CH})\end{array}$ & $\begin{array}{l}\text { Materials or packages with a surface exposure rate }<200 \mathrm{mR} / \mathrm{h} \text { may be } \\
\text { handled without shielding for radiation workers. }\end{array}$ \\
\hline Remote Handled (RH) & $\begin{array}{l}\text { Materials or packages with a surface exposure rate }>200 \mathrm{mR} / \mathrm{h} \text { must be } \\
\text { handled remotely for protection of radiation workers. Individual sites may } \\
\text { have upper limits, as well [30]. }\end{array}$ \\
\hline $\begin{array}{l}\text { Hazardous Waste } \\
\text { (Mixed Waste, MW) }\end{array}$ & $\begin{array}{l}\text { Waste that contains both hazardous material, regulated under RCRA by the } \\
\text { EPA, and radioactive material, regulated under the AEA and its by the NRC } \\
\text { or DOE, is called mixed waste. There are high-level mixed wastes, low-level } \\
\text { mixed wastes, and TRU mixed wastes (DOE treats all of its TRU waste as } \\
\text { mixed waste [31]). EPA has not yet determined whether SNF will be } \\
\text { designated as mixed waste. }\end{array}$ \\
\hline
\end{tabular}


It is apparent from examination of the definitions in Tables 1-3 that some of the classes have no lower limits. This means that no level of radioactivity, not even natural levels of radioactivity, are statutorially exempted from radioactive waste regulations and guidelines. The AEA grants the NRC power to make rulings establishing wastes as below regulatory concern (BRC or de minimis). Wastes so classified may be released as non-radioactive [32], although states may continue to regulate materials that the NRC exempts [33]. Currently there is neither a standard BRC concentration of radioactive materials nor is there a generic BRC dose level. The NRC's last attempt to define a standard was specifically retracted and eliminated by the Energy Policy Act of 1992 [34]. But the NRC reserves authority to make caseby-case BRC rulings. Case-by-case rulings are, in fact, the only de minimis rulings that are conceptually consistent and compatible with the structure of the NRC's and the DOE's radiation protection regulations.

Rather than dictate restrictive dose limits below which regulation is unecessary, both NRC and DOE in their radiation protection guidelines and regulations proscribe somewhat higher dose limits (sometimes a large fraction of the general limit to the public from all pathways of $100 \mathrm{mrem} / \mathrm{y}$ ) with the expectation that the ALARA principle will make generators reduce dose burdens well below the limits. The ALARA principle (as low as reasonably achievable) states that doses should be reduced based on a cost/benefit calculation. A guideline for "reasonably achievable" used by the NRC originally in regulating worker exposures, and later in backfits and "forward-fits" for severe accidents, in decommissioning, and transportation, has been $\$ 1,000$ per person-rem-averted (in 1983 dollars) [35]. Used strictly, this would indicate that any dose reduction that is more cost-efficient than $\$ 1000$ / person-rem must be pursued. With a linear dose-response relationship (used by legislative mandate in the United States) such a cost/benefit calculation does not depend on the absolute dose level. That is, regardless of whether the total annual dose to a member of the public is 5 mrem or $55 \mathrm{mrem}$, the cost and benefit of reducing the dose rate to the same population by $3 \mathrm{mrem} / \mathrm{y}$ is the same. Thus while case-by-case BRC rulings are essentially cost/benefit assessments in themselves, under a linear, no-threshold dose-response relationship the establishment of a generic, absolute level below which the regulating agency does not concern itself, is inconsistent with the ALARA principle.

The waste-class definitions listed in Table 1 are obviously not the only categories used to classify radioactive materials. Agencies classify waste for a variety of purposes. Table 3 lists some of the other designations used for radioactive materials under the AEA and other regulations. The AEA specifically designates special nuclear material as a class for security or nonproliferation purposes because 
of the material's essential role in nuclear weapons. Materials are also subclassified for worker hazards, or for transportation. The remainder of this paper focuses on waste classification for disposal purposes. But some of the most thorny nuclearmaterials-management problems are not yet "waste" problems according to the classification system. DOE's Integrated Data Base [17] refers to these materials as "material not considered as waste (MNCAW)." The above-mentioned disposition of $\mathrm{wPu}$ is not yet a waste issue, and the unique features of plutonium make disposition of 50 metric tons of this material ${ }^{5}$ a problem requiring national attention. Another nuclear-materials-management problem that is bound to become a waste problem is depleted uranium (DU) from uranium enrichment. In contrast to $\mathrm{wPu}$, it is the magnitude of this waste stream rather than its character that makes it such a problem. Estimates place the U.S. inventory of DU at approximately 585,000 metric tons (mostly in the form of $\mathrm{UF}_{6}$ at enrichment plants [36]). The Integrated Data Base terms waste as generated, treated, stored, or disposed, which aids in accounting for waste that fits into the existing classes, but it does not even mention $w \mathrm{Pu}$ and $\mathrm{DU}$ because they are not wastes. Unless and until these materials are officially considered waste, they will not be categorized within the system.

\footnotetext{
${ }^{5}$ Approximately $2.5 \mathrm{~m}^{3}$ of material, in its pure metallic form, but also enough to form the pits for at least 10,000 nuclear weapons.
} 


\section{Bases for Waste Classification}

Rather than having a common basis for each waste class in its classification system, such as a set of classes based on a combination of the heat-generation rate and the half-life, the U.S. system has some classes that share one basis and others that share another. As noted above, the classes in Table 1 are source-defined except for the catch-all categories: transuranic waste (TRU) and low-level waste (LLW). Specific classes were created for sources of waste that are of concern either because of their intense radioactivity (HLW and spent nuclear fuel) or because of the immense volume of material (uranium mill tailings). LLW is defined to include any material covered by the AEA that does not fit the definitions of the source-defined classes and TRU. Each of these classes is based on some characteristic of the waste itself so that the generator, without knowing the destination of the waste, can determine the waste class. And although the U.S. system has so-called orphan wastes, classification schemes like this one can be designed to neatly divide all wastes into categories that neither overlap nor omit needed material-disposition paths. These features make this kind of system more attractive to waste generators.

But policies and practices are shifting. Parallel to the regulations that define waste classes, government agencies have promulgated radiation-protection standards to protect the public health. ${ }^{6}$ These regulations address both general exposures and exposures due to disposal of radioactive waste. Regulations require operators of disposal sites to assess the anticipated performance of their facilities and, at least within DOE, to construct waste-acceptance criteria based on the capabilities, susceptibilities, and capacities of their facilities. The waste limits correspond to the dose limits to the public. A disposal site's waste-acceptance criteria are the final words on disposition of wastes at that site and are therefore effectively the final words on waste classification at that location. Because sites differ, one finds location-dependent disposal criteria, and the neatly divided waste streams begin to have ragged edges. Having the disposal site control waste flows may reflect a growing recognition of the legitimacy and importance of concerns about waste management.

It is worthwhile, then, to make higher-level distinctions between different waste-classification schemes. In what I will call a top-down waste-classification system, the waste class is based solely on the characteristics of the waste, not on the disposal environment. This includes source-defined classes, such as spent nuclear fuel in Table 1, classes based on simply measured waste characteristics, such as the

\footnotetext{
${ }^{6}$ The evolution of radiation-protection standards is an interesting story in itself. A brief treatment of
} this history can be found in Chapter 2 of Reference [37]. 
above-mentioned "contact handling" limit, and classes based on detailed wastecomposition information such as the NRC's LLW classes (derived concentrations corresponding to site-generic assessments of multipathway exposures of the public). Historically, all of the U.S. radioactive-waste classes have been top-down classes. We can contrast such top-down classes with what I will call a bottom-up wasteclassification system in which the waste class is based on the characteristics of the particular disposal site and facility and on the behavior of waste disposed there. Site-specific waste-acceptance criteria are a bottom-up waste-classification system. Thus in the United States we now have both kinds of system at the same time. The resulting conflicts arise partly from the tension between the interests of the generator and those of the disposer. To the extent that we consider both of these sets of interests to be important, we must simply accept that a tension exists. But the U.S. system is not necessarily responsive to the needs of either. The U.S. system has evolved incrementally, with development driven by pressing needs both to respond to real and perceived crises and to maintain as much consistency with past practice as possible. As a result, the U.S. system is disorderly. 


\section{Class Conflict}

The top-down approach and the bottom-up approach do not conflict $a$ priori-wastes generated by the same process often have the same characteristics and even the same inventories-but as the generators and disposal locations increase in number and variety the likelihood of overlaps and omissions increases. Further, having a consistent underlying principle as the basis is important in precisely the situations where one has conflicts and omissions. The potential difficulties are apparent in the waste streams in the United States.

The HLW and TRU waste streams are unlikely to display difficulties in classification as a result of clashes between top-down definitions and wasteacceptance criteria. Only one repository is planned for disposal of TRU waste and the plan for a second HLW repository has become increasingly hypothetical since the NWPAA in 1987 identified Yucca Mountain as the only site to be extensively characterized for the first repository. The waste-acceptance criteria for these disposal sites are expected to preclude virtually none of the waste streams destined for disposal there. Thus the potential for conflict is averted by broad waste-acceptance criteria and narrow options for disposal. But having only one disposal facility for a class of wastes poses other problems. While almost no waste is likely to be excluded based on physical characteristics, such as exposure rate or heat generation (criticality limits may be the only exception), there are waste streams that are simply too voluminous to dispose in the deep geologic repositories, notably the contaminated solid materials from environmental restoration at DOE sites. Current estimates place the untreated volume of TRUW from environmental restoration, and destined for ex-situ management, at approximately $80,000 \mathrm{~m}^{3}\left(65,000 \mathrm{~m}^{3}\right.$ from the Savannah River Site alone) [17]. If disposed at the Waste Isolation Pilot Plant (WIPP) facility without volume reduction, this material would eat up over $45 \%$ of the disposal capacity $\left(175,000 \mathrm{~m}^{3}\right.$ total). These wastes arise from cleanup activities at contaminated sites and facilities. The quantities and classes of waste that require disposal depend strongly on the remedy selected for the contamination. Because the management plans and the disposal volume are still undetermined, this waste does not appear in accountings of waste destined for WIPP.

The situation for LLW is substantially more complicated. Commercial LLW is the responsibility of the state where it was generated. Most states have formed compacts with other states so that one disposal site will serve all members of the compact. Except by special agreement, the disposal sites will accept waste only from their compact members. The host state for a disposal facility may, if it is an "agreement state" (a state with an agency acting under the authority of NRC), set 
radiation protection guidelines that are equivalent to, or more restrictive than, NRC guidelines (see Footnote a in Table 1). Each waste disposal site also establishes its own practices regarding concentration averaging. In 1993 the NRC put out a Branch Technical Position on concentration averaging [38] which suggests a "rule of ten": for homogeneous waste streams, concentrations of limiting radionuclides in components placed in the same package must be within a factor of ten of each other. For wastes containing particular radionuclides (viz. the major gamma-emitters) the limit is a factor of 1.5. While the NRC position may standardize practices to some extent, each site makes its own determination of site practices. The concentration limits for waste accepted for near-surface burial at commercial disposal facilities (such as Hanford, Barnwell, and the proposed facility at Ward Valley) are not, however, established on a site-specific basis; they are the NRC "top-down" limits used to define the Class C limit.

The NRC established dose limits for exposure from LLW-disposal facilities. The limits pertain to a set of scenarios including intruder scenarios and radionuclide-migration scenarios. To establish simple, uniform criteria for determination of waste class, the NRC worked backwards from the dose limits using the intruder scenarios to find activity-concentration limits for some of the most hazardous long-lived fission and activation products. ${ }^{7}$ The intruder scenarios establish volumetric concentration limits. These calculations were performed on a site-generic basis.

The NRC concluded that, unlike the intruder scenarios, the migration scenarios depended on the total inventory of a radionuclide (rather than the concentration) disposed at the site and would therefore require site-specific analysis. The company managing a LLW facility does performance assessments to establish the volume of waste that can be accepted given projections of the character of the waste stream. In rare cases, the total-inventory limits must be so restrictive that they impact the specific-activity limits $\left({ }^{226} \mathrm{Ra}\right.$ at Ward Valley). But generally, the facilities simply place greater waste-form requirements on waste containing some problem radionuclides, such as ${ }^{3} \mathrm{H}$, and limit the total disposable inventory of others. Any NRC-licensed LLW with concentrations of radionuclides that exceed

\footnotetext{
${ }^{7}$ The adequacy of this short list and the accuracy of the values were questioned almost immediately after their adoption by the NRC - the NRC recognized some of the shortcomings prior to adopting the rule and planned to expand the analysis: "... it is recognized that there are several isotopes ... for which concentration limits should be developed. Developments of concentration limits for such radionuclides are planned subsequently." (pages 7-21 and 7-22 of [39]). The NRC further gave itself discretion to consider alternative values "The Commission may, upon request or on its own initiative, authorize other provisions for the classification and characteristics of waste on a specific basis, if, after evaluation, of the specific characteristics of the waste, disposal site, and method of disposal, it finds reasonable assurance of compliance with the performance objectives in subpart C of this part."
} 
the limits in 10 CFR 61.55, that is waste designated as greater-than-class-C (GTCC) waste, is the responsibility of the DOE [40] and must be disposed in a facility licensed by NRC.

DOE has its own LLW streams and disposal facilities. As mentioned above, DOE does performance and safety assessments of their facilities to construct sitespecific waste-acceptance criteria. These assessments cover intruder, migration, and accident scenarios that yield concentration limits, facility limits, and package limits, respectively. Within DOE, LLW is preferentially disposed at the site of generation, wherever that is possible. If waste cannot be disposed at the generator site, either because the site does not have disposal capacity or because the waste does not qualify for disposal at the site's disposal facility, then DOE can transfer the waste to another site for disposal. Sites that have disposal facilities store or transfer, rather than dispose of, waste that exceeds the concentration limits designated in their wasteacceptance criteria. If transfered to other sites the waste might qualify for nearsurface burial or require less conditioning. For example, the Savannah River Site has some of the most restrictive concentration limits for disposal of LLW because of its high water table and recharge rate. Waste that does not qualify for near-surface burial at SRS might then be transfered to Hanford (WHC) or the Nevada Test Site (NTS), the only two DOE sites that currently accept waste from other sites. These sites have less restrictive concentration limits and could dispose as LLW some fraction of the waste streams disqualified from disposal in other DOE sites. Further, because each site has some flexibility in management of the facility, concentration averaging can be varied to accommodate shipments requiring special consideration. NTS, in fact, does not currently have concentration limits; they have action levels that indicate the need for special consideration [41]. Because of the greater flexibility and, in some cases, the higher concentration limits (by as much as a factor of 12 at Hanford [42]) at DOE disposal sites, some of the GTCC waste from the commercial sector would qualify for near-surface burial, were it DOE waste. But because NRC must license the disposal of NRC-licensed GTCC waste, it is unlikely that commercial waste will be disposed in DOE LLW facilities. Thus waste that is marked as GTCC or "greater confinement" waste (so termed because the regulations state that GTCC must go to greater confinement) must be stored as it awaits a disposal plan. Absent development of a repository specifically for GTCC waste, the waste is to be disposed of with Defense HLW and spent fuel in a high-level-waste repository (which must be licensed by NRC anyway), effectively treating GTCC waste as another form of high-level waste. A small quantity of waste will have concentrations exceeding site-specific limits at Hanford and NTS but falling short of the NRC's GTCC definition, but these small quantities are likely to be accommodated using case-by-case exemptions. 
While transfers of waste between sites likely prove to be economically efficient, they raise objections from the residents of the region to which the waste is transferred. One of the objections to siting a HLW repository at Yucca Mountain has been an argument based on equity and fairness. Most of the nation's nuclear power plants operate in the eastern half of the country while Yucca Mountain is in Nevada, in the West. Nevada, in fact, has no nuclear power plants. Due to the connectivity of the electricity-supply grid, Nevada still uses some nuclear power, but siting the repository in Nevada dissociates the benefits of nuclear power, the electricity and the revenues and jobs associated with its generation, from the environmental burden of the waste. Geographic displacement of the costs from the benefits, some claim, is unfair. By creating regional compacts, the LLWPA forces states or regions to take responsibility for disposing of their own waste. And while in a compact the waste from the entire compact goes to one state, that state cannot be forced to host the facility. On the DOE side, one interpretation of the efficiency argument is that Hanford and NTS must bear the burden of the worst waste not because they have benefited from its generation, but because the generators created waste that is too hazardous for the generators to bear the burden themselves.

The largest transfers of waste will arise from environmental restoration. Environmental restoration is expected to generate quantities of LLW that dwarf any other single radioactive waste stream (estimated at 43 million $\mathrm{m}^{3}$ plus 13 million $\mathrm{m}^{3}$ MLLW, untreated [17]), with the possible exception of UMT ( 30 million $\mathrm{m}^{3}$ [17]). But there are more remedy, management, and disposal options for LLW than with the TRUW from environmental restoration, mentioned above. While huge quantities of contaminated soil and debris will doubtless be shipped to Hanford's Megatrench, the NTS LLW disposal facility, and the Envirocare facility in Utah as LLW, LLW is more likely to be managed or remedied in situ. Were this not the case, the nation's disposal capacity for LLW would easily be exhausted by this waste stream alone (compare the above volumes to the total volume of DOE LLW disposed through 1995, 3 million $\mathrm{m}^{3}$ [17]). The result of creating on-site disposal cells for major cleanups, such as superfund sites, will be a constellation of closed LLW and perhaps even MLLW disposal units scattered all across the nation.

This last set of wastes, mixed wastes, poses a particularly challenging problem for anyone charged with managing them. The difficulty stems from the fact that EPA's approach to regulation of the hazardous component of the waste differs drastically from NRC and DOE's approach to regulating the radioactive components of the waste; and the hazardous components are not easily separable from the radioactive components. Hazardous waste must undergo a treatment process before 
disposal. In radioactive-waste management, handling is ideally minimized to avoid unnecessary worker exposure. Both kinds of waste must be disposed in specially qualified facilities, but the specifications for these facilities are rather different: the restrictions on hazardous waste disposal facilities focusing on physical measures for assurance of protection in the near term, and the restrictions on radioactive waste disposal facilities focusing on projected protectiveness in the long term. DOE, by far the largest generator of mixed waste, would like to dispose of mixed waste in existing DOE facilities. DOE has applied to EPA for a "no migration" variance for the WIPP facility, which would qualify the facility for RCRA, Subtitle C license for disposal of hazardous wastes. The same may have to happen for the HLW repository: HLW is, almost by definition, mixed waste and EPA has not yet determined whether spent nuclear fuel is mixed waste. DOE's LLW disposal sites do not meet the standard licensing requirements for a RCRA license (e.g., trenches are not lined) and it is unlikely that the facilities will qualify for a no-migration variance. DOE has asked EPA for relief from RCRA disposal regulations for DOE's treated LLMW. If EPA rejects the request, DOE faces the prospect of constructing new disposal facilities qualified under both RCRA and the AEA. 


\section{Conclusion}

Within the United States we have taken disposal to mean the permanent emplacement of waste in the earth in a manner such that, after a brief period of monitoring and active maintenance, institutional control could be abandoned without damaging human health and the environment. But several attempts at disposal (the AEC facilities mentioned in Section 2, and commercial facilities at Maxey Flats and West Valley), and even attempts at short-term management (such as Hanford), have fallen far short of the our hopes for disposal. Most of the problems arose out of insufficient restrictions on waste forms (the untreated hazardous chemicals), disposal facilities that by nature or poor design saw infiltration, or a combination that resulted in facilities that failed because the designs and the waste forms were incompatible. Lessons have been learned from experience and some of these problems have been addressed, but fundamentally the tension between top-down classes defined by the generator and bottom-up considerations based on the disposal environment has not been resolved, and the government has not effected integrated planning for management of nuclear materials in the country.

There appears, for example, to be a continued disconnect between the designers of disposal facilities and the policy and decision makers. Performance assessments are generally carried out with a set of assumptions about the waste streams corresponding to the classes of waste designated for disposal at the site. Little consideration is given to problem wastes within known waste classes, such as spent fuel from research reactors. And as the wastes that do not fit, the so-called "orphan wastes" such as greater-than-class-C low-level waste (GTCC LLW), excess weapons-grade plutonium, and mixed waste, are redirected for co-disposal with other wastes, the waste stream changes. In the case of GTCC LLW, the waste forms will be radically different from those used in modeling of the high-level waste repository thus far. It is not yet clear whether this is a simple or a difficult problem to resolve.

We have now in the United States a unique opportunity to restructure the waste-classification system. The above discussion indicates that there is a strong linkage between actual disposal facilities and officially established waste classes. Only three commercial low-level waste disposal facilities are currently operating and the nation has not yet opened for operations disposal facilities for any other kind of waste (tailings and byproduct wastes excepted). Thus we have an opportunity to redefine waste classes, to base them more on the factors that are important for waste management, before directions are set and inertia is established. But this opportunity is a window that will not stay open for long. Several more 
commercial LLW disposal facilities are hoped to begin operations in the next decade. WIPP is scheduled to begin accepting waste in the year 1998. Plans for cleanup of the DOE complex have been put onto a fast track, a ten-year plan announced in 1996 by DOE's head of Environmental Management.

Any new system of classification needs to include considerations that drive both the top-down systems and the bottom-up systems: they exist for good reason. But our current system does not do a good job of matching the waste to its destination. When the disposal is not properly suited to the waste or the waste is not suited for the disposal, it is possible to spend more for less protection. Thus, the cost of keeping our current disorderly classes and not integrating the interests of generators and disposers into a systematic scheme may be higher risks, higher expenditures, or both. 


\section{Acknowledgments}

I gratefully acknowledge the assistance and input of Jesse Yow, Larry Ramspott, Bill Kastenberg, Tom Isaacs, Jor-Shan Choi, and Jessica Booher for their thoughtful comments and suggestions and for providing information. This work was funded under the Nuclear Materials Stewardship Initiative at Lawrence Livermore National Laboratory and was carried out at the Center for Nuclear and Toxic Waste Management at the University of California at Berkeley. 


\section{Appendix A:}

\section{Acronyms}

\begin{tabular}{|c|c|}
\hline AEA & Atomic Energy Act \\
\hline AEC & Atomic Energy Committee \\
\hline ALARA & As low as reasonably achievable \\
\hline BRC & Below Regulatory Concern \\
\hline CERCLA & Comprehensive Environmental Response, Compensation and Liability Act \\
\hline CFR & Code of Federal Regulations \\
\hline DOE & Department of Energy \\
\hline DOT & Department of Transportation \\
\hline DU & Depleted Uranium \\
\hline EPA & Environmental Protection Agency \\
\hline ERDA & Energy Research and Development Agency \\
\hline FR & Federal Register \\
\hline GTCC & Greater-than-class-C \\
\hline HLW & High-level waste \\
\hline INEL & Idaho National Engineering Laboratory \\
\hline INEEL & Idaho National Engineering and Environmental Laboratory \\
\hline LLMW & Low-level mixed waste \\
\hline LLW & Low-level waste \\
\hline LLWPA & Low-Level Waste Policy Act \\
\hline LLWPAA & Low-Level Waste Policy Amendments Act \\
\hline MNCAW & Material not considered as waste \\
\hline MTU & Metric tons Uranium \\
\hline MW & Mixed waste \\
\hline NARM & Naturally occurring and accelerator-produced radioactive material \\
\hline NAS & National Academy of Sciences \\
\hline NAS-NRC & National Academy of Sciences - National Research Council \\
\hline NRC & Nuclear Regulatory Commission \\
\hline NTS & Nevada Test Site \\
\hline NWPA & Nuclear Waste Policy Act \\
\hline NWPAA & Nuclear Waste Policy Amendments Act \\
\hline RCRA & Resource Conservation and Recovery Act \\
\hline TSCA & Toxic Substances Control Act \\
\hline TRU & Transuranic \\
\hline TRUW & Transuranic waste \\
\hline UMT & Uranium mill tailings \\
\hline USC & United States Code \\
\hline WIPP & Waste Isolation Pilot Plant \\
\hline wPu & Weapons-grade Plutonium \\
\hline
\end{tabular}




\section{Appendix B:}

\section{A Comparison of LLW Concentration Limits}

The tables in this appendix illustrate the variation in concentration limits from site to site. In Table B-1 I have included the waste-acceptance criteria from three DOE LLW sites: Hanford (category 1 correllates by scenario to class A, and category 3 correllates to class C) [42], the Savannah River Site's E-Area Vaults [43], and the Nevada Test Site [41]. Also included are the concentration limits from the NRC's definitions of the LLW classes from the Code of Federal Regulations (CFR) [28]. Commercial LLW sites do conduct performance assessments, but not to establish sitespecific concentration limits. Instead, they accept waste that is qualified as LLW according to the NRC's definitions and the performance assessments establish total inventory limits based on calculations using reference waste streams. Thus the CFR limits can be used for comparison with the DOE waste acceptance criteria.

Typically, the concentration limits follow the "sum-of-the-fractions rule." The sum-of-the-fractions rule states that the concentration of each listed radionuclide will be divided by the specific-activity limit for that radionuclide and the sum of these fractions must not exceed 1 for the waste class corresponding to those limits to apply. In other words, if the sum of the fractions is greater than 1, then the waste does not qualify for near-surface burial, if the concentrations limits are for class C LLW. The NRC has two lists of limits, one for long-lived radionuclides and one for short-lived radionuclides, and the first table should be applied on its own unless no radionuclides from that list are present, in which case the second list is to be used. The Savannah River Site's E-Area Vaults also have multiple lists. Some correspond to particular vaults (see Table B-1) and others represent calculations other than those in the performance assessment, such as criticality concerns. The limit for fissile material in the E-Area Vaults is 50 grams of U-235 fissile gram equivalent (50 FGE U-235). This criterion is represented by the equation

$$
50 \geq \sum_{i} E F_{i} \cdot M_{i},
$$

where $E F_{i}$ is the equivalence factor for radionuclide $\mathrm{i}$, from Table $\mathrm{B}-3$, and $M_{i}$ is the allowed mass of radionuclide $i$, from Table B-2. The E-Area Vaults have further restrictions that make their limits compatible with other standards: no waste disposed at the E-Area Vaults may exceed the NRC's limits for class C LLW, and no waste may have concentrations of transuranics in excess of $100 \mathrm{nCi} / \mathrm{g}$ (the TRU lower bound).

Each of the three DOE sites listed has a facility for storage of greater-than-classC waste. 
Table B-1

\begin{tabular}{|c|c|c|c|c|c|c|c|c|c|c|}
\hline \multirow[t]{2}{*}{ Radionuclide } & \multicolumn{2}{|c|}{ Hanford } & \multirow[t]{2}{*}{10 CFR $61^{a}$} & \multicolumn{6}{|c|}{ Savannah Riverb } & \multirow[t]{2}{*}{ NTS } \\
\hline & Category 1 & Category 3 & & LAWV & ILNTV 1 & ILNTV 2 & ILTV Bulk & ILTV cruc & LLWSB & \\
\hline $\mathrm{H}-3$ & $5.00 \mathrm{E}+06$ & $\mathrm{c}$ & 40 (Class A, 2) & $3.68 \mathrm{E}+00$ & $3.68 \mathrm{E}+00$ & $3.68 \mathrm{E}+00$ & $6.25 \mathrm{E}+01$ & $1.47 \mathrm{E}+04$ & $3.68 \mathrm{E}+03$ & $1.51 \mathrm{E}+05$ \\
\hline $\mathrm{Be}-10$ & $1.00 \mathrm{E}+00$ & $2.20 \mathrm{E}+02$ & $\mathrm{c}$ & $\mathrm{c}$ & $\mathrm{c}$ & $\mathrm{c}$ & $\mathrm{c}$ & $\mathrm{c}$ & $\bar{c}$ & $\mathrm{c}$ \\
\hline $\mathrm{C}-14^{\mathrm{d}}$ & $4.00 \mathrm{E}-02$ & $9.10 \mathrm{E}+00$ & $8(1)$ & $1.21 \mathrm{E}-03$ & $1.43 \mathrm{E}-03$ & $8.46 \mathrm{E}-03$ & $2.06 \mathrm{E}-03$ & $2.91 \mathrm{E}-03$ & $8.46 \mathrm{E}+03$ & $6.22 \mathrm{E}-03$ \\
\hline Al-26 & $\mathrm{c}$ & $\mathrm{c}$ & $\mathrm{c}$ & $4.78 \mathrm{E}-05$ & $5.89 \mathrm{E}-05$ & $3.61 \mathrm{E}-04$ & $8.46 \mathrm{E}-05$ & $\mathrm{c}$ & $\mathrm{c}$ & $\mathrm{c}$ \\
\hline $\mathrm{Cl}-36$ & $4.00 \mathrm{E}-04$ & $8.30 \mathrm{E}-02$ & $\mathrm{c}$ & $\mathrm{c}$ & $\mathrm{c}$ & $\mathrm{c}$ & $\mathrm{c}$ & $\mathrm{c}$ & $\mathrm{c}$ & $2.97 \mathrm{E}-01$ \\
\hline $\mathrm{K}-40$ & $1.70 \mathrm{E}-03$ & $3.40 \mathrm{E}-01$ & $\mathrm{c}$ & $\mathrm{c}$ & $\mathrm{c}$ & $\mathrm{c}$ & $\mathrm{c}$ & $\mathrm{c}$ & $\mathrm{c}$ & $\mathrm{c}$ \\
\hline Co-60 & $7.70 \mathrm{E}+01$ & $\bar{c}$ & $\begin{array}{c}700 \text { (Class A, } \\
2 \text { ) } \\
\end{array}$ & $8.46 \mathrm{E}+00$ & $8.46 \mathrm{E}+00$ & $6.62 \mathrm{E}+02$ & $6.62 \mathrm{E}+02$ & $9.93 \mathrm{E}+01$ & $8.46 \mathrm{E}-01$ & $\mathrm{c}$ \\
\hline Ni-59() & $4.00 \mathrm{E}+00$ & $8.30 \mathrm{E}+02$ & $22(1)$ & $2.32 \mathrm{E}-02$ & $2.58 \mathrm{E}-01$ & $1.55 \mathrm{E}+00$ & $3.68 \mathrm{E}-01$ & $5.15 \mathrm{E}-01$ & $8.46 \mathrm{E}-01$ & $2.19 \mathrm{E}+02$ \\
\hline Ni-63 () & $4.80 \mathrm{E}+00$ & $1.70 \mathrm{E}+04$ & $700(2)$ & $\mathrm{c}$ & $\mathrm{c}$ & $\mathrm{c}$ & $\bar{c}$ & $\mathrm{c}$ & $\bar{c}$ & $7.03 \mathrm{E}+03$ \\
\hline Se-79 & $3.80 \mathrm{E}-01$ & $8.30 \mathrm{E}+01$ & $\mathrm{c}$ & $1.91 \mathrm{E}-04$ & $8.46 \mathrm{E}-04$ & $6.62 \mathrm{E}-03$ & $8.46 \mathrm{E}-04$ & $6.62 \mathrm{E}-04$ & $8.46 \mathrm{E}-01$ & $\bar{c}$ \\
\hline Sr-90 & $4.30 \mathrm{E}-03$ & $1.50 \mathrm{E}+04$ & $7000(2)$ & $4.05 \mathrm{E}+00$ & $8.46 \mathrm{E}+00$ & $6.62 \mathrm{E}+02$ & $8.46 \mathrm{E}+00$ & $6.62 \mathrm{E}+01$ & $8.46 \mathrm{E}+01$ & $4.05 \mathrm{E}+01$ \\
\hline $\mathrm{Zr}-93$ & $2.70 \mathrm{E}+00$ & $5.90 \mathrm{E}+02$ & $\mathrm{c}$ & $7.73 \mathrm{E}-02$ & $8.46 \mathrm{E}-01$ & $6.62 \mathrm{E}+01$ & $5.89 \mathrm{E}+00$ & $\mathrm{c}$ & $\mathrm{c}$ & $3.78 \mathrm{E}+02$ \\
\hline Nb-94 () & $2.60 \mathrm{E}-04$ & $5.60 \mathrm{E}-02$ & $0.02(1)$ & $\mathrm{c}$ & $\mathrm{c}$ & $\mathrm{c}$ & $\mathrm{c}$ & $\mathrm{c}$ & $\mathrm{c}$ & $\mathrm{c}$ \\
\hline Mo-93 & $3.00 \mathrm{E}-01$ & $7.10 \mathrm{E}+01$ & $\mathrm{c}$ & $\mathrm{c}$ & $\mathrm{c}$ & $\mathrm{c}$ & $\mathrm{c}$ & $\mathrm{c}$ & $\mathrm{c}$ & $\mathrm{c}$ \\
\hline Tc-99 & $5.60 \mathrm{E}-03$ & $1.20 \mathrm{E}+00$ & 3 & $6.25 \mathrm{E}-05$ & $2.87 \mathrm{E}-04$ & $1.73 \mathrm{E}-03$ & $4.05 \mathrm{E}-04$ & $5.89 \mathrm{E}-04$ & $8.46 \mathrm{E}+02$ & $2.97 \mathrm{E}+00$ \\
\hline Pd-107 & $4.80 \mathrm{E}+00$ & $1.00 \mathrm{E}+03$ & $\mathrm{c}$ & $\mathrm{c}$ & $\mathrm{c}$ & $\mathrm{c}$ & $\mathrm{c}$ & $\mathrm{c}$ & $\mathrm{c}$ & $3.51 \mathrm{E}+03$ \\
\hline Cd-113m & $2.00 \mathrm{E}-01$ & $\mathrm{c}$ & $\mathrm{c}$ & $\mathrm{c}$ & $\mathrm{c}$ & $\mathrm{c}$ & $\mathrm{c}$ & $\mathrm{c}$ & $\mathrm{c}$ & $\mathrm{c}$ \\
\hline Sn-121m & $6.30 \mathrm{E}+00$ & $2.00 \mathrm{E}+05$ & $\mathrm{c}$ & $\mathrm{c}$ & $\mathrm{c}$ & $\mathrm{c}$ & $\mathrm{c}$ & $\mathrm{c}$ & $\mathrm{c}$ & $\mathrm{c}$ \\
\hline Sn-126 & $1.80 \mathrm{E}-04$ & $\mathrm{c}$ & $\mathrm{c}$ & $1.07 \mathrm{E}-04$ & $8.46 \mathrm{E}-04$ & $6.62 \mathrm{E}-03$ & $8.46 \mathrm{E}-04$ & $6.62 \mathrm{E}-04$ & $8.46 \mathrm{E}-01$ & $1.59 \mathrm{E}-02$ \\
\hline I-129 & $2.90 \mathrm{E}-03$ & $5.90 \mathrm{E}-01$ & 0.08 (1) & $3.05 \mathrm{E}-08$ & $7.73 \mathrm{E}-08$ & $4.41 \mathrm{E}-07$ & $1.07 \mathrm{E}-07$ & $1.55 \mathrm{E}-07$ & $8.46 \mathrm{E}+01$ & $8.11 \mathrm{E}-02$ \\
\hline Ba-133 & $7.70 \mathrm{E}-01$ & $\mathrm{c}$ & $\mathrm{c}$ & $\mathrm{c}$ & $\mathrm{c}$ & $\mathrm{c}$ & $\mathrm{c}$ & $\mathrm{c}$ & $\mathrm{c}$ & $\mathrm{c}$ \\
\hline Cs-135 & $1.90 \mathrm{E}-01$ & $4.20 \mathrm{E}+01$ & $\mathrm{c}$ & $\mathrm{c}$ & $\mathrm{c}$ & $\mathrm{c}$ & $\mathrm{c}$ & $\mathrm{c}$ & $\mathrm{c}$ & $7.57 \mathrm{E}+01$ \\
\hline Cs-137 & $6.30 \mathrm{E}-03$ & $1.30 \mathrm{E}+04$ & $4600(2)$ & $2.80 \mathrm{E}-01$ & $8.46 \mathrm{E}+01$ & $6.25 \mathrm{E}+02$ & $8.46 \mathrm{E}+01$ & $6.62 \mathrm{E}+01$ & $8.46 \mathrm{E}+01$ & $9.19 \mathrm{E}+00$ \\
\hline Sm-147 & $1.60 \mathrm{E}-02$ & $3.40 \mathrm{E}+00$ & $\mathrm{c}$ & $\mathrm{c}$ & $\mathrm{c}$ & $\bar{c}$ & $\mathrm{c}$ & $\mathrm{c}$ & $\bar{c}$ & $\bar{c}$ \\
\hline Sm-151 & $3.80 \mathrm{E}+01$ & $1.80 \mathrm{E}+05$ & $\mathrm{c}$ & $\mathrm{c}$ & $\bar{c}$ & $\bar{c}$ & c & $\bar{c}$ & $\bar{c}$ & $3.24 \mathrm{E}+04$ \\
\hline Eu-150 & $1.60 \mathrm{E}-03$ & $7.70 \mathrm{E}+02$ & $\bar{c}$ & $\bar{c}$ & $\bar{c}$ & $\bar{c}$ & $\mathrm{c}$ & $\bar{c}$ & $\bar{c}$ & $\mathrm{c}$ \\
\hline Eu-152 & $5.30 \mathrm{E}-02$ & $\mathrm{c}$ & $\mathrm{c}$ & $\mathrm{c}$ & $\mathrm{c}$ & $\mathrm{c}$ & $\mathrm{c}$ & $\mathrm{c}$ & $\mathrm{c}$ & $1.30 \mathrm{E}+03$ \\
\hline Eu-154 & $8.30 \mathrm{E}-01$ & $\mathrm{c}$ & $\mathrm{c}$ & $\mathrm{c}$ & $\mathrm{c}$ & $\mathrm{c}$ & $\mathrm{c}$ & $\mathrm{c}$ & $\mathrm{c}$ & $3.24 \mathrm{E}+05$ \\
\hline Gd-152 & $6.30 \mathrm{E}-03$ & $1.30 \mathrm{E}+00$ & $\mathrm{c}$ & $\mathrm{c}$ & $\mathrm{c}$ & $\mathrm{c}$ & $\mathrm{c}$ & $\mathrm{c}$ & $\mathrm{c}$ & $\mathrm{c}$ \\
\hline Re-187 & $5.30 \mathrm{E}+00$ & $1.10 \mathrm{E}+03$ & $\mathrm{c}$ & $\mathrm{c}$ & $\mathrm{c}$ & $\mathrm{c}$ & $\mathrm{c}$ & $\mathrm{c}$ & $\bar{c}$ & $\mathrm{c}$ \\
\hline Po-209 & $2.90 \mathrm{E}-02$ & $7.70 \mathrm{E}+01$ & $\mathrm{c}$ & $\mathrm{c}$ & $\bar{c}$ & $\mathrm{c}$ & $\mathrm{c}$ & $\mathrm{c}$ & $\bar{c}$ & $\bar{c}$ \\
\hline $\mathrm{Pb}-210$ & $1.00 \mathrm{E}-02$ & $5.60 \mathrm{E}+05$ & $\mathrm{c}$ & $\mathrm{c}$ & $\bar{c}$ & $\mathrm{c}$ & $\mathrm{c}$ & $\mathrm{c}$ & $\bar{c}$ & $3.51 \mathrm{E}+02$ \\
\hline Bi-207 & $\bar{c}$ & $\mathrm{c}$ & $\mathrm{c}$ & $\bar{c}$ & $\bar{c}$ & $\bar{c}$ & $\mathrm{c}$ & $\mathrm{c}$ & $\bar{c}$ & $2.97 \mathrm{E}+00$ \\
\hline $\mathrm{Ra}-226$ & $1.40 \mathrm{E}-04$ & $3.60 \mathrm{E}-02$ & $\mathrm{c}$ & $\mathrm{c}$ & $\mathrm{c}$ & $\mathrm{c}$ & $\mathrm{c}$ & $\mathrm{c}$ & $\mathrm{c}$ & $3.51 \mathrm{E}-02$ \\
\hline $\mathrm{Ra}-228$ & $1.90 \mathrm{E}+01$ & $\mathrm{c}$ & $\mathrm{c}$ & $\mathrm{c}$ & $\mathrm{c}$ & $\mathrm{c}$ & $\mathrm{c}$ & $\mathrm{c}$ & $\mathrm{c}$ & $\mathrm{c}$ \\
\hline Ac-227 & $4.50 \mathrm{E}-03$ & $3.20 \mathrm{E}+05$ & $\mathrm{c}$ & $\mathrm{c}$ & $\mathrm{c}$ & $\mathrm{c}$ & $\mathrm{c}$ & $\mathrm{c}$ & $\mathrm{c}$ & $2.70 \mathrm{E}+01$ \\
\hline
\end{tabular}

${ }^{a}$ Limits listed are the Class $\mathrm{C}$ limits, unless otherwise noted. The sum-of-the-fractions rule is to be applied to the radionuclides from Table 1 of 10 CFR 61.55 (tables are denoted in parentheses next to the limit) unless no radionuclide from Table 1 is present in the waste, in which case the rule is applied to the radionuclides from Table 2 of 10 CFR 61.55. $\mathrm{b}$ The concentrations quoted for the Savannah River E-Area Vaults (EAV) have been converted from package limits (Ci/package) based on the assumption of a standard package size: 4 feet $\times 4$ feet $\times 6$ feet, or $96 \mathrm{ft}^{3}\left(2.718 \mathrm{~m}^{3}\right)$. The categories at Savannah River refer to specific vaults: LAWV=Low-activity waste vault, ILNTV=Intermediate-level nontritium vault ( $1=$ combustible, $2=$ noncombustible), ILTV=Intermediate-level tritium vault (bulk or crucibles), LLWSB=Long-lived waste storage building (for waste that does not qualify for disposal at Savannah River EAV).

${ }^{c}$ There is no limit established for this radionuclide in this category.

$\mathrm{d}$ The limit for this radionuclide is higher by a factor of 10 (except at Savannah River and NTS) if the radionuclide is a product of activation in metal. 
Table B-2

\begin{tabular}{|c|c|c|c|c|c|c|c|c|c|c|}
\hline \multirow[t]{2}{*}{ Radionuclide } & \multicolumn{2}{|c|}{ Hanford } & \multirow[t]{2}{*}{ 10CFR61.55 } & \multicolumn{6}{|c|}{ Savannah River E-Area Vaults } & \multirow[t]{2}{*}{ NTS } \\
\hline & Category 1 & Category 3 & & LAWV & ILNTV 1 & ILNTV 2 & ILTV Bulk & ILTV cruc & LLWSB & \\
\hline Th-229 & $4.80 \mathrm{E}-04$ & $1.10 \mathrm{E}-01$ & $\mathrm{a}$ & a & a & a & a & a & a & $1.11 \mathrm{E}-01$ \\
\hline Th-230 & $2.10 \mathrm{E}-03$ & $1.30 \mathrm{E}-01$ & $\mathrm{a}$ & $\mathrm{a}$ & $\mathrm{a}$ & $\bar{a}$ & $\mathrm{a}$ & $\bar{a}$ & $\mathrm{a}$ & $8.38 \mathrm{E}-02$ \\
\hline Th-232 & $1.20 \mathrm{E}-04$ & $2.20 \mathrm{E}-02$ & $\mathrm{a}$ & $\mathrm{a}$ & $\bar{a}$ & $\bar{a}$ & $\mathrm{a}$ & $\mathrm{a}$ & $\mathrm{a}$ & $2.19 \mathrm{E}-02$ \\
\hline $\mathrm{Pa}-231$ & $1.60 \mathrm{E}-04$ & $3.30 \mathrm{E}-02$ & $\bar{a}$ & $\bar{a}$ & $\bar{a}$ & $\bar{a}$ & $\bar{a}$ & $\bar{a}$ & $\bar{a}$ & $3.78 \mathrm{E}-02$ \\
\hline U-232 & $5.30 \mathrm{E}-04$ & $4.00 \mathrm{E}+00$ & $\bar{a}$ & $1.36 \mathrm{E}-04$ & $6.62 \mathrm{E}-03$ & $2.72 \mathrm{E}-01$ & $4.78 \mathrm{E}-03$ & $\bar{a}$ & $\bar{a}$ & $2.51 \mathrm{E}-01$ \\
\hline U-233 & $7.70 \mathrm{E}-03$ & $1.10 \mathrm{E}+00$ & $\bar{a}$ & $1.21 \mathrm{E}-05$ & $1.21 \mathrm{E}-05$ & $1.21 \mathrm{E}-05$ & $1.21 \mathrm{E}-05$ & $1.21 \mathrm{E}-05$ & $1.21 \mathrm{E}-05$ & $8.38 \mathrm{E}-01$ \\
\hline U-234 & $9.10 \mathrm{E}-03$ & $2.10 \mathrm{E}+00$ & $\bar{a}$ & $2.76 \mathrm{E}-03$ & $2.76 \mathrm{E}-03$ & $8.46 \mathrm{E}-03$ & $2.76 \mathrm{E}-02$ & $2.91 \mathrm{E}-03$ & $8.46 \mathrm{E}-02$ & $1.00 \mathrm{E}+00$ \\
\hline U-235 & $3.20 \mathrm{E}-03$ & $5.90 \mathrm{E}-01$ & $\mathrm{a}$ & $4.05 \mathrm{E}-05$ & $4.05 \mathrm{E}-05$ & $4.05 \mathrm{E}-05$ & $4.05 \mathrm{E}-05$ & $3.42 \mathrm{E}-06$ & $4.05 \mathrm{E}-05$ & $3.24 \mathrm{E}-01$ \\
\hline U-236 & $1.00 \mathrm{E}-02$ & $2.20 \mathrm{E}+00$ & $\bar{a}$ & $5.15 \mathrm{E}-04$ & $8.46 \mathrm{E}-04$ & $6.62 \mathrm{E}-01$ & $8.46 \mathrm{E}-03$ & $6.62 \mathrm{E}-03$ & $8.46 \mathrm{E}-02$ & $3.24 \mathrm{E}+00$ \\
\hline U-238 & $6.30 \mathrm{E}-03$ & $1.40 \mathrm{E}+00$ & $\bar{a}$ & $8.46 \mathrm{E}-04$ & $8.46 \mathrm{E}-04$ & $4.41 \mathrm{E}-02$ & $8.46 \mathrm{E}-03$ & $6.62 \mathrm{E}-03$ & $8.46 \mathrm{E}-02$ & $1.59 \mathrm{E}+00$ \\
\hline Np-237 & $1.90 \mathrm{E}-04$ & $4.00 \mathrm{E}-02$ & $\bar{a}$ & $8.09 \mathrm{E}-06$ & $2.87 \mathrm{E}-05$ & $1.73 \mathrm{E}-04$ & $4.05 \mathrm{E}-05$ & $5.89 \mathrm{E}-05$ & $8.46 \mathrm{E}-02$ & $1.89 \mathrm{E}-02$ \\
\hline $\mathrm{Pu}-236$ & $\bar{a}$ & $\mathrm{a}$ & $\mathrm{a}$ & $\bar{a}$ & $\bar{a}$ & $\bar{a}$ & $\bar{a}$ & $a$ & $\bar{a}$ & $6.22 \mathrm{E}+00$ \\
\hline $\mathrm{Pu}-238$ & $9.10 \mathrm{E}-03$ & $4.50 \mathrm{E}+01$ & $\bar{a}$ & $3.35 \mathrm{E}-02$ & $8.46 \mathrm{E}-02$ & $6.62 \mathrm{E}-01$ & $8.46 \mathrm{E}-02$ & $6.62 \mathrm{E}-02$ & $8.46 \mathrm{E}-02$ & $3.24 \mathrm{E}+00$ \\
\hline $\mathrm{Pu}-239$ & $3.60 \mathrm{E}-03$ & $7.70 \mathrm{E}-01$ & $\mathrm{a}$ & $3.35 \mathrm{E}-02$ & $8.46 \mathrm{E}-02$ & $6.62 \mathrm{E}-01$ & $8.46 \mathrm{E}-02$ & $6.62 \mathrm{E}-02$ & $8.46 \mathrm{E}-02$ & $6.22 \mathrm{E}-01$ \\
\hline $\mathrm{Pu}-240$ & $3.60 \mathrm{E}-03$ & $7.70 \mathrm{E}-01$ & $\mathrm{a}$ & $3.35 \mathrm{E}-02$ & $8.46 \mathrm{E}-02$ & $6.62 \mathrm{E}-01$ & $8.46 \mathrm{E}-02$ & $6.62 \mathrm{E}-02$ & $8.46 \mathrm{E}-02$ & $6.22 \mathrm{E}-01$ \\
\hline $\mathrm{Pu}-241$ & $7.70 \mathrm{E}-02$ & $3.10 \mathrm{E}+01$ & 3500nCi/g (1) & $4.05 \mathrm{E}-01$ & $9.93 \mathrm{E}-01$ & $8.09 \mathrm{E}+00$ & $9.93 \mathrm{E}-01$ & $8.09 \mathrm{E}-01$ & $9.93 \mathrm{E}-01$ & $1.41 \mathrm{E}+01$ \\
\hline $\mathrm{Pu}-242$ & $3.80 \mathrm{E}-03$ & $8.30 \mathrm{E}-01$ & $\mathrm{a}$ & $3.35 \mathrm{E}-02$ & $8.46 \mathrm{E}-02$ & $6.62 \mathrm{E}-01$ & $8.46 \mathrm{E}-02$ & $6.62 \mathrm{E}-02$ & $8.46 \mathrm{E}-02$ & $6.49 \mathrm{E}-01$ \\
\hline $\mathrm{Pu}-244$ & $8.30 \mathrm{E}-04$ & $1.70 \mathrm{E}-01$ & $\mathrm{a}$ & $a$ & $a$ & $a$ & $a$ & $\mathrm{a}$ & $\mathrm{a}$ & $\mathrm{a}$ \\
\hline Am-241 & $2.60 \mathrm{E}-03$ & $1.10 \mathrm{E}+00$ & $\bar{a}$ & $3.35 \mathrm{E}-02$ & $8.46 \mathrm{E}-02$ & $6.62 \mathrm{E}-01$ & $8.46 \mathrm{E}-02$ & $6.62 \mathrm{E}-02$ & $8.46 \mathrm{E}-02$ & $4.86 \mathrm{E}-01$ \\
\hline Am-242m & $2.60 \mathrm{E}-03$ & $2.40 \mathrm{E}+00$ & $\bar{a}$ & $a$ & $a$ & $\bar{a}$ & $a$ & $\bar{a}$ & $\bar{a}$ & $\bar{a}$ \\
\hline Am-243 & $1.30 \mathrm{E}-03$ & $2.80 \mathrm{E}-01$ & $\mathrm{a}$ & $1.21 \mathrm{E}-03$ & $3.02 \mathrm{E}-03$ & $1.80 \mathrm{E}-02$ & $4.41 \mathrm{E}-03$ & $\mathrm{a}$ & $\bar{a}$ & $1.89 \mathrm{E}-01$ \\
\hline $\mathrm{Cm}-242$ & $\mathrm{a}$ & $\mathrm{a}$ & $\begin{array}{c}20,000 \mathrm{nCi} / \mathrm{g} \\
(1) \\
\end{array}$ & $\mathrm{a}$ & $\mathrm{a}$ & $\mathrm{a}$ & $\mathrm{a}$ & $\mathrm{a}$ & $\mathrm{a}$ & $6.49 \mathrm{E}+02$ \\
\hline $\mathrm{Cm}-243$ & $2.50 \mathrm{E}-02$ & $6.30 \mathrm{E}+02$ & $\mathrm{a}$ & $\mathrm{a}$ & $\mathrm{a}$ & $\mathrm{a}$ & $\mathrm{a}$ & $\mathrm{a}$ & $\mathrm{a}$ & $\mathrm{a}$ \\
\hline $\mathrm{Cm}-244$ & $2.30 \mathrm{E}-01$ & $2.90 \mathrm{E}+02$ & $\mathrm{a}$ & $\mathrm{a}$ & $\mathrm{a}$ & $\mathrm{a}$ & $\mathrm{a}$ & $\mathrm{a}$ & $\mathrm{a}$ & $2.19 \mathrm{E}+02$ \\
\hline $\mathrm{Cm}-245$ & $2.10 \mathrm{E}-03$ & $3.30 \mathrm{E}-01$ & $\mathrm{a}$ & $1.36 \mathrm{E}-04$ & $6.62 \mathrm{E}-03$ & $4.41 \mathrm{E}-02$ & $4.78 \mathrm{E}-03$ & $\mathrm{a}$ & $\mathrm{a}$ & $\mathrm{a}$ \\
\hline $\mathrm{Cm}-246$ & $3.30 \mathrm{E}-01$ & $7.70 \mathrm{E}-01$ & $\mathrm{a}$ & $1.36 \mathrm{E}-04$ & $6.62 \mathrm{E}-03$ & $2.72 \mathrm{E}-01$ & $4.78 \mathrm{E}-03$ & $\mathrm{a}$ & $\mathrm{a}$ & $a$ \\
\hline $\mathrm{Cm}-247$ & $7.10 \mathrm{E}-04$ & $1.50 \mathrm{E}-01$ & $\mathrm{a}$ & $1.36 \mathrm{E}-04$ & $5.89 \mathrm{E}-04$ & $3.53 \mathrm{E}-03$ & $8.46 \mathrm{E}-04$ & $a$ & $\mathrm{a}$ & $a$ \\
\hline $\mathrm{Cm}-248$ & $9.10 \mathrm{E}-04$ & $2.00 \mathrm{E}-01$ & $\mathrm{a}$ & $4.05 \mathrm{E}-03$ & $8.46 \mathrm{E}-02$ & $6.62 \mathrm{E}-01$ & $1.51 \mathrm{E}-02$ & $a$ & $a$ & $1.70 \mathrm{E}-01$ \\
\hline Cf-249 & $\mathrm{a}$ & $\mathrm{a}$ & $\mathrm{a}$ & $1.36 \mathrm{E}-04$ & $6.62 \mathrm{E}-03$ & $2.72 \mathrm{E}-01$ & $4.78 \mathrm{E}-03$ & $\mathrm{a}$ & $\mathrm{a}$ & $\mathrm{a}$ \\
\hline Cf-251 & $\mathrm{a}$ & $\mathrm{a}$ & $\mathrm{a}$ & $1.36 \mathrm{E}-04$ & $6.62 \mathrm{E}-03$ & $2.72 \mathrm{E}-01$ & $4.78 \mathrm{E}-03$ & $\mathrm{a}$ & $\mathrm{a}$ & $\mathrm{a}$ \\
\hline Other $\beta \& \gamma$ & $\mathrm{a}$ & $\mathrm{a}$ & $\mathrm{a}$ & $8.46 \mathrm{E}-01$ & $8.46 \mathrm{E}+00$ & $6.62 \mathrm{E}+02$ & $5.89 \mathrm{E}+01$ & $4.78 \mathrm{E}+02$ & $8.46 \mathrm{E}+01$ & $\mathrm{a}$ \\
\hline Other $\alpha$ & $\mathrm{a}$ & $\mathrm{a}$ & $\begin{array}{c}100 \mathrm{nCi} / \mathrm{g} \\
\left(\mathrm{t}_{1 / 2}<5 \mathrm{y}\right)(1)\end{array}$ & $1.36 \mathrm{E}-03$ & $6.62 \mathrm{E}-02$ & $2.72 \mathrm{E}-01$ & $4.78 \mathrm{E}-03$ & $6.62 \mathrm{E}-02$ & $7.36 \mathrm{E}-02$ & $\mathrm{a}$ \\
\hline
\end{tabular}

a There is no limit established for this radionuclide in this category.

Table B-3

\begin{tabular}{|c|c|}
\hline Radionuclide & Equivalence Factor \\
\hline $\mathrm{U}-233$ & 1.4 \\
\hline $\mathrm{U}-235$ & 1 \\
\hline $\mathrm{Pu}-239$ & 1.6 \\
\hline $\mathrm{Pu}-241$ & 3.5 \\
\hline $\mathrm{Am}-242 \mathrm{~m}$ & 54 \\
\hline
\end{tabular}

\begin{tabular}{|c|c|}
\hline Radionuclide & Equivalence Factor \\
\hline Cm-243 & 7.8 \\
\hline Cm-245 & 24 \\
\hline Cm-247 & 1.6 \\
\hline Cf-249 & 70 \\
\hline Cf-251 & 140 \\
\hline
\end{tabular}




\section{References}

[1] The McMahon Atomic Energy Act of 1946, Aug. 1, 1946, ch. 724, 60 Stat. 755.

[2] The Atomic Energy Act Amendments of 1954, Aug. 30, 1954, ch. 1073, Sec. 1, 68 Stat. 919.

[3] Federal Register: April 1, 1983 (Volume 48) Page 14146.

[4] Hess, H.H., J.N. Adkins, W.E. Benson, J.C. Frye, W.B. Heroy, M.K. Hubbert, R.J. Russell, C.V. Theis, The Disposal of Radioactive Waste on Land: Report of the Committee on Waste Disposal of the Division of Earth Sciences; National Academy of Sciences - National Research Council, Publication 519, Washington, DC, 1957.

[5] Berlin, R.E., C.C. Stanton, Radioactive Waste Management, John Wiley \& Sons, New York (1989).

[6] Solid Waste Disposal Act of 1965, P.L. 89-272.

[7] Resource Conservation and Recovery Act of 1976, P.L. 94-580.

[8] Comprehensive Environmental Response, Compensation, and Liability Act of 1980, P.L. 96-510.

[9] Uranium Mill Tailings Radiation Control Act of 1978 Pub. L. 95-604.

[10] The Low-Level Radioactive Waste Policy Act, P.L. 96-573, Dec. 22, 1980, 94 Stat. 3347 (U.S.C. Title 42, Sec. $2021 \mathrm{~b}$ et seq.).

[11] The Nuclear Waste Policy Act, P.L. 97-425, Jan. 7, 1983, 96 Stat. 2201 (Title 42, Sec. 10101 et seq.).

[12] The Low-Level Radioactive Waste Policy Amendments Act of 1985, P.L. 99-240, title I, Jan. 15, 1986, 99 Stat. 18420.

[13] Nuclear Waste Policy Amendments Act of 1987, P.L. 100-203, title V, subtitle A, Sec. 5001-5065, Dec. 22, 1987, 101 Stat. 1330-227 to 1330-255.

[14] Energy Reorganization Act of 1974, P.L. 93-438, Oct. 11, 1974, 88 Stat. 1233, (U.S.C. Title 42, Sec. 5801 et seq.).

[15] Federal Facility Compliance Act of 1992, P. L. 102-386, title I, Oct. 6, 1992, 106 Stat.

[16] DOE Order 5820.2 (1984) and replaced by 5820.2A in 1988, both titled "Radioactive Waste Management."

[17] Oak Ridge National Laboratory Integrated Data Base Report-1995: U.S. Spent Fuel and Radioactive Waste Inventories, Projections, and Characteristics, DOE/RW-006, Rev. 12, December 1996.

[18] United States Code, title 42, sections 2011 et seq. (42 U.S.C. § 2011 et seq.).

[19] Fri, R.W., J.F. Ahearne, J.M Bahr, R.D. Banks, R.J. Budnitz, S. Burstein, M.W. Carter, C. Fairhurst, C. McCombie, F.M. Phillips, T.H. Pigford, A.C. Upton, C.G. Whipple, G.F. White, S.D. Wiltshire, Technical Bases for Yucca Mountain Standards; National Academy of SciencesNational Research Council, National Academy Press,Washington, D.C. 1995.

[20] Holdren, J.P., "Radioactive-Waste Management in the United States: Evolving Policy Prospects and Dilemmas," Annual Review of Energy and Environment, vol. 17 (1992): pp235-259.

[21] United States Code, title 42, section 10101 (42 U.S.C. § 10101).

[22] U.S. Code of Federal Regulations, Title 10, Part 60.2 (10 C.F.R. 60.2).

[23] United States Code, title 42, section 2014 (42 U.S.C. § 2014).

[24] United States Code, title 42, section 2021 (42 U.S.C. § 2021).

[25] U.S. Code of Federal Regulations, Title 40, Part 61 (40 C.F.R. 61).

[26] Federal Register: July 21, 1995 (Volume 60, Number 140) Page 37556-37565.

[27] The League of Women Voters Education Fund, The Nuclear Waste Primer 1993 Revised Edition, Lyons \& Burford, New York (1993): pp 25-26.

[28] U.S. Code of Federal Regulations, Title 10, Part 61 (10 C.F.R. 61).

[29] United States Code, title 42, section 2091 (42 U.S.C. § 2091).

[30] Carson, P.H., G.D. Pierce, and R.L. Morton "Sources of Waste" Radioactive Waste Management and the Nuclear Fuel Cycle, vol 14 (1-2), 1990: pp 27-44.

[31] Oak Ridge National Laboratory Integrated Data Base (IDB) for 1993: U.S. Spent Fuel and Radioactive Waste Inventories, Projections, and Characteristics, DOE/RW-006, Rev. 9, March 1994.

[32] "Radioactive waste below regulatory concern," 42 U.S.C. $§ 2021 j$. 
[33] "State authority to regulate radiation below level of regulatory concern of Nuclear Regulatory Commission," 42 U.S.C. 2023.

[34] The Energy Policy Act of 1992, Pub. L. 102-486, Oct. 24, 1992, 106 Stat. 2776.

[35] Mubayi, V., V. Sailor, and G. Anadalingam, Cost Benefit Considerations in Regulatory Analysis, NUREG/CR-6349, Brookhaven National Laboratory, BNL-NUREG-52466, October 1995.

[36] U.S. Department of Energy, Taking Stock: A Look at the Opportunities and Challenges Posed by Inventories from the Cold War Era, Volume 1 of the Materials in Inventory Initiative, DOE/EM0275, January 1996.

[37] U.S. Environmental Protection Agency, "Background Information Document: Final Rule for HighLevel and Transuranic Radioactive Wastes," EPA 520/1-85-023, August 1985.

[38] U.S. Nuclear Regulatory Commission, "Branch Technical Position on Concentration Averaging and Encapsulation," January 17, 1995.

[39] "Responsibilities for disposal of low-level radioactive waste" 42 U.S.C. § 2021c (b) (1) (D).

[40] Office of Nuclear Materials Safety and Safeguards, Draft Environmental Impact Statement on 10 CFR Part 61 "Licensing Requirements for Land Disposal of Radioactive Waste," U.S. Nuclear Regulatory Commission, NUREG-0782, vol.2-4, September 1981.

[41] "Nevada Test Site Waste Acceptance Criteria" NTSWAC (Rev. 0), September 1996.

[42] "Low-Level Waste Acceptance Criteria," Section 3, WHC-EP-0063-4.

[43] "WSRC 1S SRS Waste Acceptance Criteria: Procedure 3.10 E-Area Vaults Low-Level Radioactive Solid Waste Acceptance Criteria," Revision No. 2, July 31, 1996. 



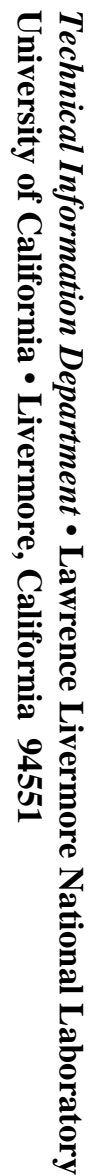

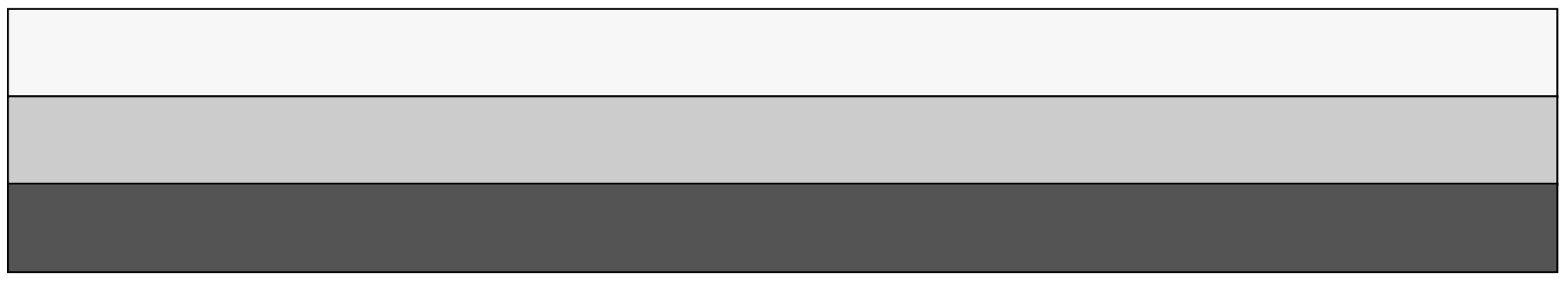

